\title{
BDNF regulates the expression and traffic of NMDA receptors in cultured hippocampal neurons
}

\author{
Margarida V. Caldeira, Carlos V. Melo, Daniela B. Pereira, Ricardo F. Carvalho, \\ Ana Luísa Carvalho, and Carlos B. Duarte* \\ Center for Neuroscience and Cell Biology, Department of Zoology, University of Coimbra, 3004-517 Coimbra, Portugal
}

Received 15 August 2006; revised 20 February 2007; accepted 22 February 2007

Available online 3 March 2007

\begin{abstract}
The neurotrophin BDNF regulates the activity-dependent modifications of synaptic strength in the CNS. Physiological and biochemical evidences implicate the NMDA glutamate receptor as one of the targets for BDNF modulation. In the present study, we investigated the effect of BDNF on the expression and plasma membrane abundance of NMDA receptor subunits in cultured hippocampal neurons. Acute stimulation of hippocampal neurons with BDNF differentially upregulated the protein levels of the NR1, NR2A and NR2B NMDA receptor subunits, by a mechanism sensitive to transcription and translation inhibitors. Accordingly, BDNF also increased the mRNA levels for NR1, NR2A and NR2B subunits. The neurotrophin NT3 also upregulated the protein levels of NR2A and NR2B subunits, but was without effect on the NR1 subunit. The amount of NR1, NR2A and NR2B proteins associated with the plasma membrane of hippocampal neurons was differentially increased by BDNF stimulation for 30 min or $24 \mathrm{~h}$. The rapid upregulation of plasma membrane-associated NMDA receptor subunits was correlated with an increase in NMDA receptor activity. The results indicate that BDNF increases the abundance of NMDA receptors and their delivery to the plasma membrane, thereby upregulating receptor activity in cultured hippocampal neurons. (C) 2007 Elsevier Inc. All rights reserved.
\end{abstract}

\section{Introduction}

The neurotrophin brain-derived neurotrophic factor (BDNF) promotes neuronal survival and differentiation, and regulates synaptic transmission and plasticity (reviewed in Bramham and Messaoudi, 2005; Kalb, 2005; Lu et al., 2005). BDNF rapidly potentiates excitatory synaptic transmission in cultured cerebrocortical and hippocampal neurons, in part by enhancing presynaptic neurotransmitter release (Lessmann and Heumann, 1998; Takei et al., 1998). Post-synaptically, BDNF enhances glutamatergic synaptic transmission by regulating the phosphorylation of NMDA ( $N$-methylD-aspartate) receptors (Suen et al., 1997; Lin et al., 1998; Alder et al.,

\footnotetext{
* Corresponding author. Fax: +351 239480208 .

E-mail address: cbduarte@ci.uc.pt (C.B. Duarte).

Available online on ScienceDirect (www.sciencedirect.com).
}

2005), thereby enhancing NMDA receptor activity (Levine et al., 1998; Song et al., 1998), increasing synaptic clustering of NMDA receptors in cultured hippocampal neurons (Elmariah et al., 2004), and upregulating AMPA receptor protein levels (Narisawa-Saito et al., 1999a). Accordingly, BDNF has been implicated in activitydependent synaptic plasticity, including the early- and late phases of long-term potentiation (LTP) induced by high-frequency stimulation (reviewed in Bramham and Messaoudi, 2005). Activity-dependent changes in synaptic strength are thought to underlie learning and memory formation (Lynch, 2004).

NMDA receptors are glutamate, glycine and voltage-dependent ion channels characterized by their high calcium permeability. In the hippocampus, NMDA receptors are heteromeric complexes composed of at least one NR1 subunit and one or more of the two subunits, NR2A and NR2B (Sheng et al., 1994). Both NR1 and NR2 subunits are required to form a functional ionotropic receptor (Meguro et al., 1992; Monyer et al., 1994; Dingledine et al., 1999), but different NR2 subunits confer distinct kinetic properties to the NMDA receptors (Monyer et al., 1994). Some NMDA receptors may also include an NR3 subunit (either NR3A or NR3B) as part of the tetrameric structure (Chatterton et al., 2002). Before synapse formation in developing hippocampal neurons, NMDA receptors consist predominantly of NR1 and NR2B subunits (Tovar and Westbrook, 1999). NR2B seems to remain in NMDA receptors that are primarily extrasynaptic after synapse formation, although NR2B-containing NMDA receptors are also found at the synapse. This subunit composition is found in NMDA receptors present in synaptic and extrasynaptic regions after synapse formation. In contrast, NR2A subunit progressively increases its expression (Monyer et al., 1994; Sheng et al., 1994; Margottil and Domenici, 2003) and is incorporated at synaptic sites (Stocca and Vicini, 1998; Tovar and Westbrook, 1999). The mechanisms controlling the switch in the composition of synaptic NMDA receptors from NR2B- to NR2Acontaining receptors are not well understood (Barria and Malinow, 2002), but studies in cortical neurons showed that the expression of NMDA receptor subunits is regulated by neuronal activity (Muzet and Dupont, 1996).

BDNF enhances the phosphorylation of NR1 and NR2B subunits in hippocampal and cortical neurons (Lin et al., 1998), and 
increases the open probability of NMDA receptor channels (Levine et al., 1998; Levine and Kolb, 2000). Phosphorylation of NR2B by Fyn was suggested to contribute to the increase of glutamatergic synaptic transmission by BDNF (Alder et al., 2005), and tyrosine phosphorylation of the NR2B subunit was also associated with LTP in the hippocampal CA1 region (Nakazawa et al., 2001). In addition to these rapid effects of BDNF on NMDA receptors, recent studies showed that BDNF increases the translation of the mRNA for NR1 in cultured cerebrocortical neurons (Schratt et al., 2004), suggesting that the neurotrophin may also regulate the abundance of NMDA receptors in the hippocampus. Although NMDA receptors were initially thought to be relatively stable in the membrane, recent studies have indicated that their surface expression is dynamic and regulated (Nong et al., 2004). Thus, the BDNF-induced upregulation of glutamatergic activity may also be due to the delivery of NMDA receptors to the plasma membrane. In the present study we investigated the short- and long-term effects of BDNF on the cellular and plasma membrane abundance of NMDA receptor subunits in cultured hippocampal neurons, and correlated the results with the effects of BDNF on the activity of the receptors.

\section{Results}

\section{Effect of BDNF on the total protein levels of NMDA receptor subunits}

To evaluate the acute effects of BDNF on the abundance of NMDA receptor subunits, 7 DIV cultured hippocampal neurons were incubated with or without $100 \mathrm{ng} / \mathrm{ml} \mathrm{BDNF}$, for various periods of time (15 min-24 h). The NMDA receptor subunit NR1, NR2A and NR2B protein levels were determined by Western Blotting (Figs. 1A, C and E). BDNF upregulated NR1 subunits rapidly and in a sustained manner. Significant effects were observed after $30 \mathrm{~min}$ to $12 \mathrm{~h}$ incubation with BDNF. The neurotrophin also did upregulate NR2A and NR2B subunits, but with a distinct kinetics. NR2A protein levels were significantly increased for longer periods of incubation with BDNF ( $3 \mathrm{~h}$ to $12 \mathrm{~h}$ ), while NR2B protein levels were enhanced by brief BDNF stimulation periods ( $1 \mathrm{~h}$ to $3 \mathrm{~h}$ ). After $24 \mathrm{~h}$ of stimulation with BDNF the NR1 and NR2A protein levels were still slightly higher than the control, whereas a small reduction of NR2B was observed. NR2C and NR2D subunits were undetectable (data not shown), consistent with the lack of these NMDA receptor subunits in the hippocampus (e.g. Janssens and Lesage, 2001). BDNF also upregulated the amount of NR1, NR2A and NR2B subunits in more mature hippocampal neurons, cultured for 14 DIV (Fletcher et al., 1991; Figs. 1B, D and F). In these cells BDNF induced a sustained increase in NR1 protein levels, particularly for incubation periods of $5 \mathrm{~h}, 6 \mathrm{~h}$ and $24 \mathrm{~h}$. The NR2A subunit was also upregulated by BDNF for long periods of incubation with BDNF (6 h, $12 \mathrm{~h}$ and $24 \mathrm{~h})$. In contrast, the NR2B subunit was upregulated only by short incubations with BDNF, as observed for 7 DIV (Fig. 1F). Activation of Trk neurotrophin receptors was required for upregulation of NR1, NR2A and NR2B receptor subunits by BDNF, since no effect was observed when neurons were incubated with heat-inactivated BDNF (Figs. 2A-C). Furthermore, pre-incubation of hippocampal neurons with the Trk inhibitor K252a abrogated the effects of BDNF, although the inhibitor also upregulated the NR1 protein levels in the absence of neurotrophin (not shown).

In contrast with the results obtained with the hippocampal neurons, incubation of cultured cerebellar granule cells with $100 \mathrm{ng} / \mathrm{ml}$
BDNF, for $2 \mathrm{~h}$ or $6 \mathrm{~h}$, did not increase the protein levels of NR1, NR2A and NR2B subunits (Figs. 2D-F). These results indicate that the BDNF-induced upregulation of the NMDA receptor subunits is specific for hippocampal neurons.

Incubation of hippocampal neurons with a different neurotrophin, neurotrophin-3 (NT3), which binds preferentially to the TrkC receptors (Dechant, 2001), also increased the protein levels of NR2A and NR2B subunits (Figs. 3B and C), but was without effect on NR1 subunit (Fig. 3A), indicating that this neurotrophin also modulates the levels of the NMDA receptor subunits.

Since BDNF is known to upregulate translation (e.g. Takei et al., 2001) we studied whether de novo protein synthesis could account for the BDNF-induced increase in NR1, NR2A and NR2B NMDA receptor subunits. We used two translation inhibitors, emetine and anisomycin, and the hippocampal neurons were stimulated with BDNF for $3 \mathrm{~h}$, in the presence or in the absence of the protein synthesis inhibitors. Pre-incubation of cells with emetine $(2 \mu \mathrm{M})$ or anisomycin $(2 \mu \mathrm{M})$ abolished the effect of BDNF on NR1, NR2A and NR2B subunits (Fig. 4). None of the protein synthesis inhibitors altered the NR1, NR2A and NR2B protein levels under control conditions. These results are in agreement with the long half-life determined for the NR2A/B subunits in cultured cerebellar granule cells, and with the turn-over rate of NR1 in the same preparation (Huh and Wenthold, 1999). Taken together, the results indicate that BDNF affects NMDA receptor subunits by increasing protein synthesis and suggest that a reduction in protein degradation is not involved.

\section{Effect of BDNF in the transcription activity of NMDA receptor subunits}

The effects of BDNF on protein synthesis may be due to an increase in transcription activity (Messaoudi et al., 2002) and/or to direct regulation of the protein synthesis machinery (Takei et al., 2001). Therefore, the role of transcription in the BDNF-induced upregulation of NR1, NR2A and NR2B protein levels was investigated using two transcription inhibitors, $\alpha$-amanitine and actinomycin D. As for the translation inhibitors, pre-incubation of the cultures with $\alpha$-amanitine $(1.5 \mu \mathrm{M})$ or actinomycin $\mathrm{D}(1.5 \mu \mathrm{M})$ abolished the BDNF-induced upregulation of the NR1, NR2A and NR2B protein levels, but was without effect on the abundance of the NMDA receptor subunits in the absence of BDNF (Fig. 5). To further confirm that the effects of BDNF occur at the transcription level, real-time PCR using the SYBR green assay was performed (Fig. 6). Stimulation with BDNF for $30 \mathrm{~min}$ or $3 \mathrm{~h}$ significantly increased the mRNA levels of NR1 and NR2A, although the effect was less significant in the latter incubation period. A delayed increase in the mRNA levels for NR2B was also observed after $3 \mathrm{~h}$ of stimulation with BDNF (Fig. 6). These results point to a regulation of NR1, NR2A and NR2B NMDA receptor subunits by BDNF at the transcription level. Moreover, they clearly correlate the several fold increase in NR1 and NR2A mRNA with the sustained raise in the respective protein levels. On the other hand, the transient increase in NR2B protein levels induced by BDNF is also correlated with a relatively weaker effect on the mRNA levels of this specific subunit.

\section{Effect of BDNF on NMDA receptor subunit protein levels at the plasma membrane}

In cerebellar granule neurons there is a large intracellular pool of NR1 subunits, whereas most NR2A and NR2B subunit proteins are 
A.
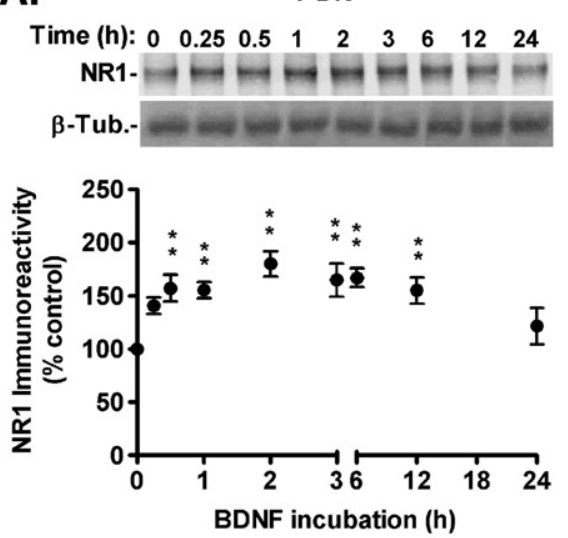

C.
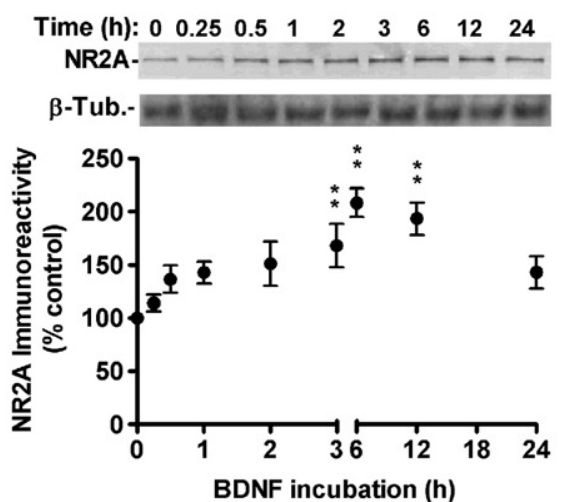

E.

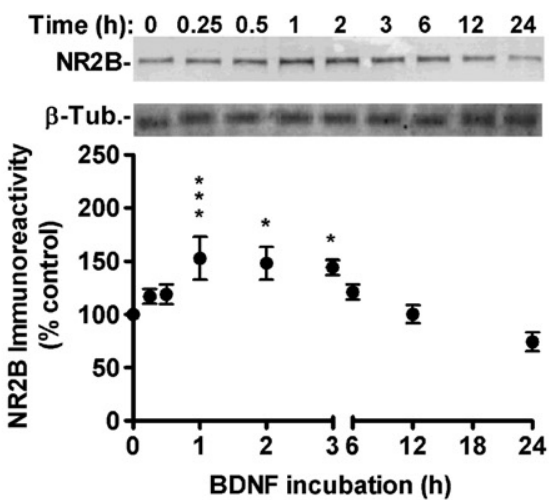

B.

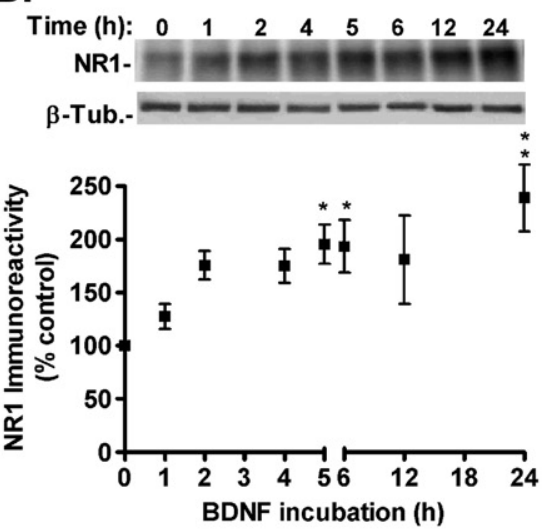

D.

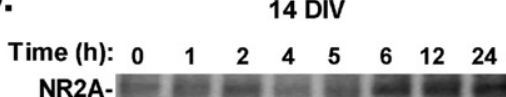

$\beta$-Tub.- $=-m=-m=$

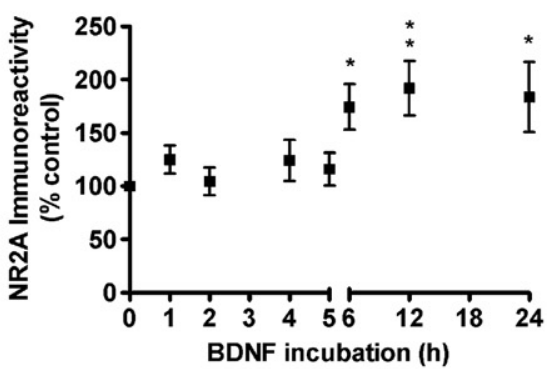

F.

14 DIV

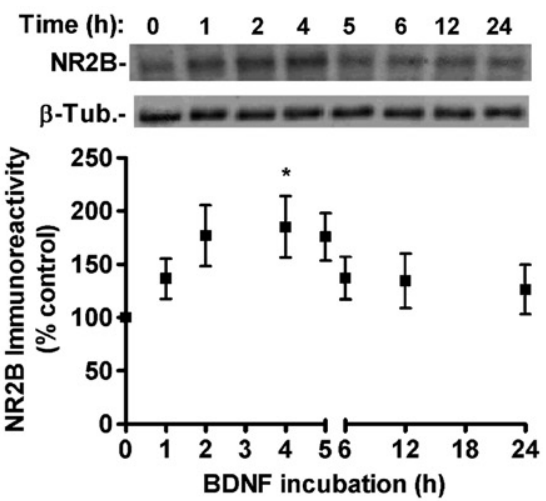

Fig. 1. BDNF upregulates the protein levels of the NR1, NR2A and NR2B NMDA receptor subunits in cultured hippocampal neurons. Seven DIV (A, C, E) or 14 DIV (B, D, F) cultured hippocampal neurons were incubated with or without $100 \mathrm{ng} / \mathrm{ml} \mathrm{BDNF}$ (15 min, $30 \mathrm{~min}, 1 \mathrm{~h}, 2 \mathrm{~h}, 3 \mathrm{~h}, 4 \mathrm{~h}, 5 \mathrm{~h}, 6 \mathrm{~h}, 12 \mathrm{~h}$ and $24 \mathrm{~h})$, as indicated. Total NR1, NR2A and NR2B protein levels were determined by Western Blot. Control ( 0 h) protein levels of NMDA receptor subunits were set to $100 \%$. $\beta$-tubulin was used as loading control. The results are the average \pm S.E.M. of $5-9$ independent experiments, performed in independent preparations. Statistical analysis was performed by one-way ANOVA, followed by the Dunnett's test. $* P<0.05, * * P<0.01$.

present on the cell surface (Huh and Wenthold, 1999). Thus, in these cells the NR2 subunit availability determines the number of cell surface receptors (Prybylowski et al., 2002). This may also apply to hippocampal neurons, where the majority of NR2B is associated with the plasma membrane, whereas a significant fraction of NR1 is intracellular (Hall and Soderling, 1997). Therefore, we investigated whether the upregulation of NMDA receptor sub- units by BDNF affects the NR1 and NR2 protein levels in the plasma membrane of cultured hippocampal neurons. The cell surface distribution of the NMDA receptor subunits NR1, NR2A and NR2B was determined by biotinylation of cell surface proteins, under control conditions and after treatment with $100 \mathrm{ng} / \mathrm{ml} \mathrm{BDNF}$. Surface proteins were then collected with streptavidin-coupled beads, and subjected to Western Blotting (Fig. 7). BDNF treatment 
A.

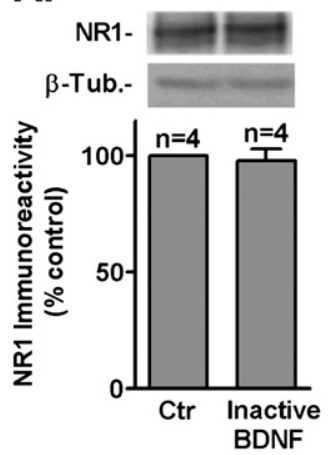

D.

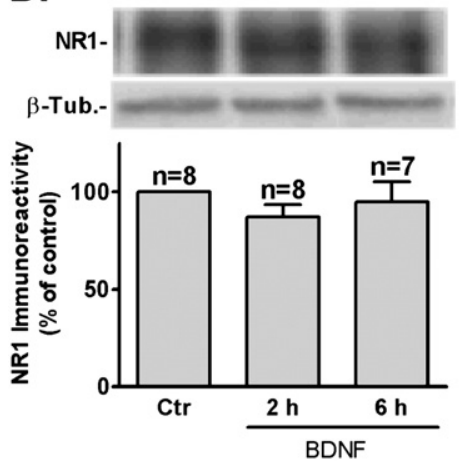

B.

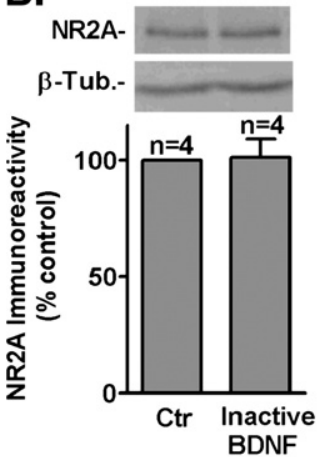

E.
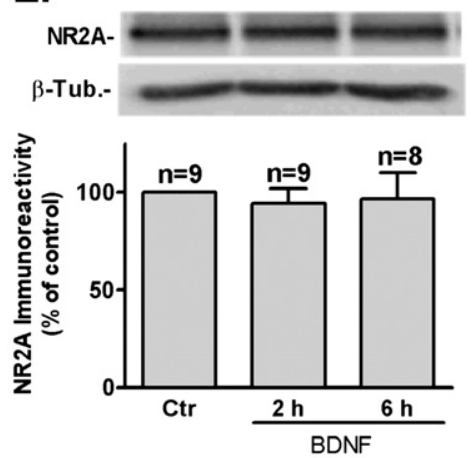

C.

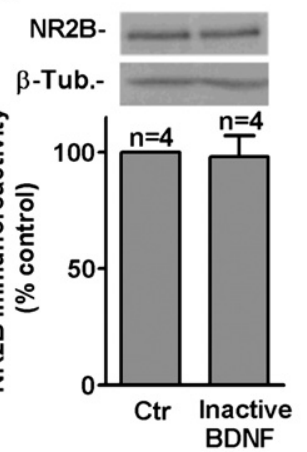

F.

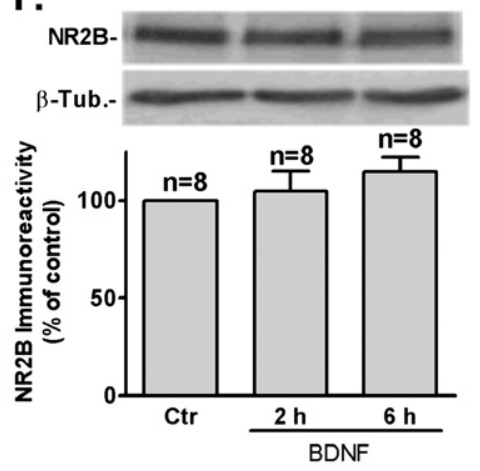

Fig. 2. Heat-inactivated BDNF does not upregulate NR1, NR2A or NR2B protein levels (A-C). Hippocampal neurons were incubated with or without 100 ng/ml heat-inactivated BDNF $\left(95^{\circ} \mathrm{C}, 5 \mathrm{~min}\right)$, for $3 \mathrm{~h}$. NR1, NR2A and NR2B protein levels were measured by Western Blot. BDNF does not affect the protein levels of NR1, NR2A and NR2B subunits in cultured cerebellar granule neurons (D-F). The cells were incubated with or without $100 \mathrm{ng} / \mathrm{ml} \mathrm{BDNF}$ ( $2 \mathrm{~h}$ and $6 \mathrm{~h}$ ), and the NR1, NR2A and NR2B protein levels were measured by Western blot. Control (unstimulated) protein levels of NMDA receptor subunits were set to $100 \%$. $\beta$ tubulin was used as loading control. The results are the average \pm S.E.M. of 4-9 independent experiments, performed in independent preparations. Statistical analysis was performed by one-way ANOVA, followed by the Dunnett's test.

during 30 min markedly increased NR1 and NR2B proteins associated with the plasma membrane, whereas longer incubations with the neurotrophin $(24 \mathrm{~h})$ were required to significantly increase surface NR2A. These data suggest that BDNF differentially regulates the translocation of the NMDA receptors with different subunit compositions to the plasma membrane in cultured hippocampal neurons.

\section{Effect of BDNF on the NMDA-induced $\left[\mathrm{Ca}^{2+}\right]_{i}$ changes}

NMDA receptors are cation channels, permeable to $\mathrm{Na}^{+}$and $\mathrm{Ca}^{2+}$, and activation of these receptors increases the intracellular free calcium concentration $\left(\left[\mathrm{Ca}^{2+}\right]_{\mathrm{i}}\right)$ (e.g. Duarte et al., 1996). The effect of BDNF on the activity of NMDA receptors was investigated in single cultured hippocampal neurons, by Fura-2 imaging.
A.
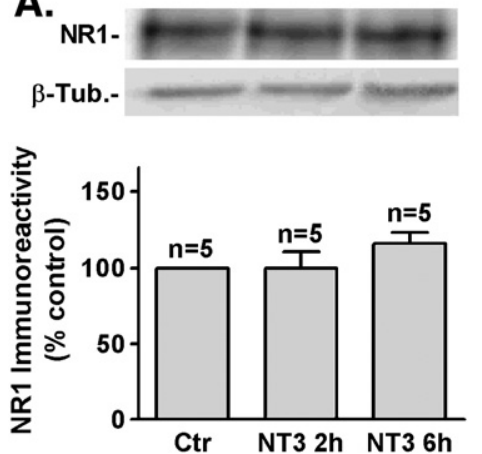

B.
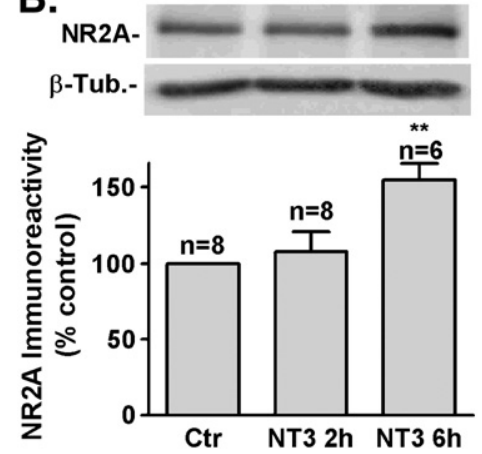

C. NR2B$\beta$-Tub.-

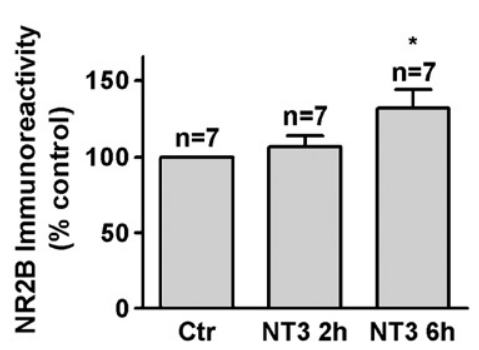

Fig. 3. Incubation of hippocampal neurons with NT3 increased the protein levels of NR2A and NR2B, but was without effect on NR1 protein levels. Seven DIV neurons were incubated with or without $100 \mathrm{ng} / \mathrm{ml} \mathrm{NT3}$ for $2 \mathrm{~h}$ and $6 \mathrm{~h}$, and total NR1 (A), NR2A (B) and NR2B (C) protein levels were measured by Western Blot. Control (unstimulated) protein levels of NMDA receptor subunits were set to $100 \%$. $\beta$-tubulin was used as loading control. The results are the average \pm S.E.M. of 5-8 independent experiments, performed in independent preparations. Statistical analysis was performed by one-way ANOVA, followed by the Dunnett's test. $* P<0.05, * * P<0.01$. 
A.

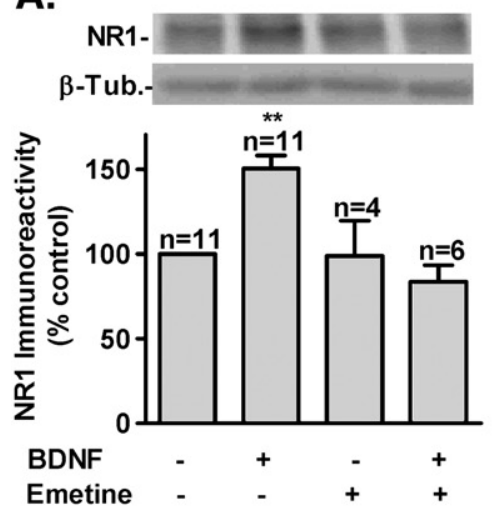

C.

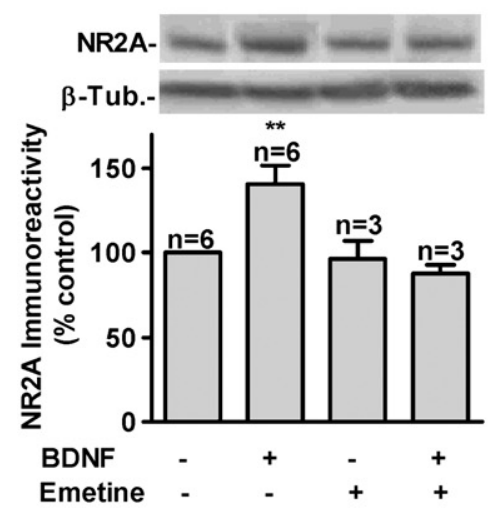

E.

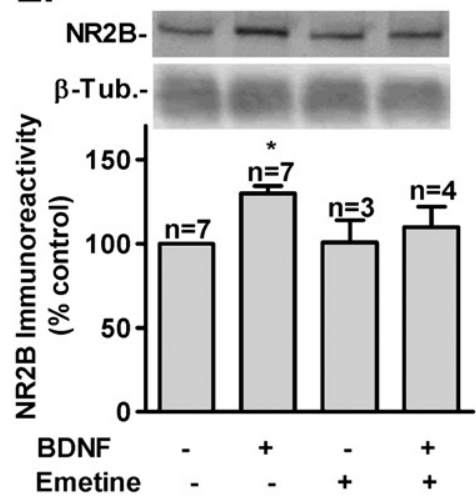

B. NR1-
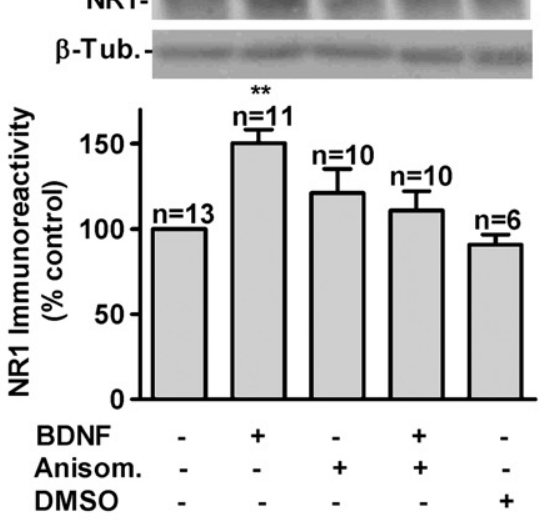

D.

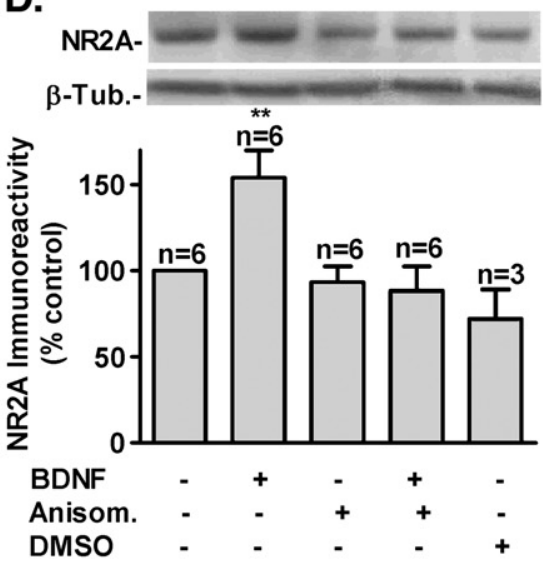

F.

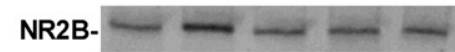

$\beta$-Tub.-

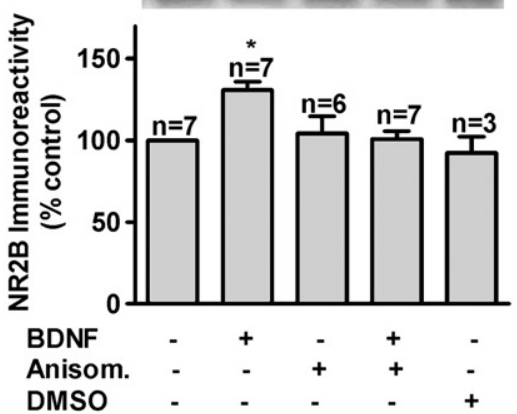

Fig. 4. Translation inhibitors impair the BDNF-induced upregulation of NR1, NR2A and NR2B protein levels. Seven DIV hippocampal neurons were incubated with or without $100 \mathrm{ng} / \mathrm{ml} \mathrm{BDNF}$ for $3 \mathrm{~h}$, in the presence or in the absence of emetine $(2.0 \mu \mathrm{M})(\mathrm{A}, \mathrm{C}, \mathrm{E})$ or anisomycin $(2.0 \mu \mathrm{M})(\mathrm{B}, \mathrm{D}, \mathrm{F})$. When the inhibitors were used the cells were pre-incubated with the compounds for 30 min before stimulation with BDNF. Total NR1, NR2A and NR2B protein levels were measured by Western Blot. Control protein levels of NMDA receptor subunits were set to $100 \%$. $\beta$-tubulin was used as loading control. The results are the average \pm S.E.M. of 6-12 independent experiments, performed in independent preparations. Statistical analysis was performed by one-way ANOVA, followed by the Dunnett's test. $* P<0.05, * * P<0.001$.

Stimulation of cultured hippocampal neurons with NMDA, in a $\mathrm{Mg}^{2+}$-free medium, increased the Fura-2 fluorescence ratio (F340/ F380) (Fig. 8). When the cells were pre-incubated with BDNF for 40 min there was an increase in the NMDA-induced $\left[\mathrm{Ca}^{2+}\right]_{\mathrm{i}}$ rise. The $\left[\mathrm{Ca}^{2+}\right]_{\mathrm{i}}$ response to activation of NMDA receptors is due to $\mathrm{Ca}^{2+}$ entry through the receptor channels and to $\mathrm{Ca}^{2+}$ influx through voltage-gated $\mathrm{Ca}^{2+}$ channels (Duarte et al., 1996). To determine whether the effect of BDNF on the responses to NMDA is due to an increase in the activity of voltage-gated $\mathrm{Ca}^{2+}$ channels, rather than to a direct change in the activity of the receptors, we studied the effect of the neurotrophin on the initial $\left[\mathrm{Ca}^{2+}\right]_{\mathrm{i}}$ changes caused by $\mathrm{KCl}$ depolarization. Perfusion of the cells with a solution where $\mathrm{NaCl}$ was isoosmotically replaced by $30 \mathrm{mM} \mathrm{KCl}$ rapidly increased the $\left[\mathrm{Ca}^{2+}\right]_{i}$, but the magnitude of the response was not affected by 

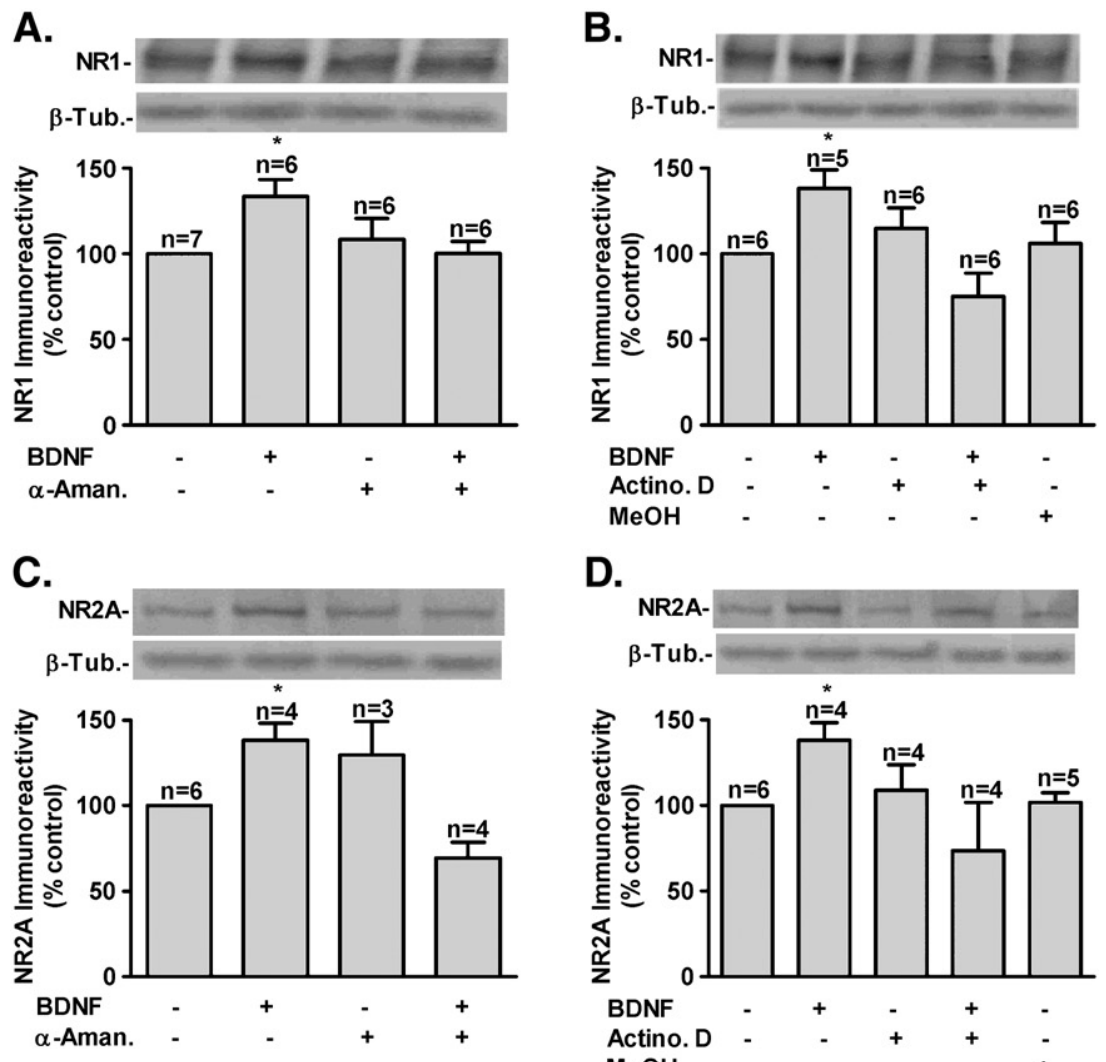

D.
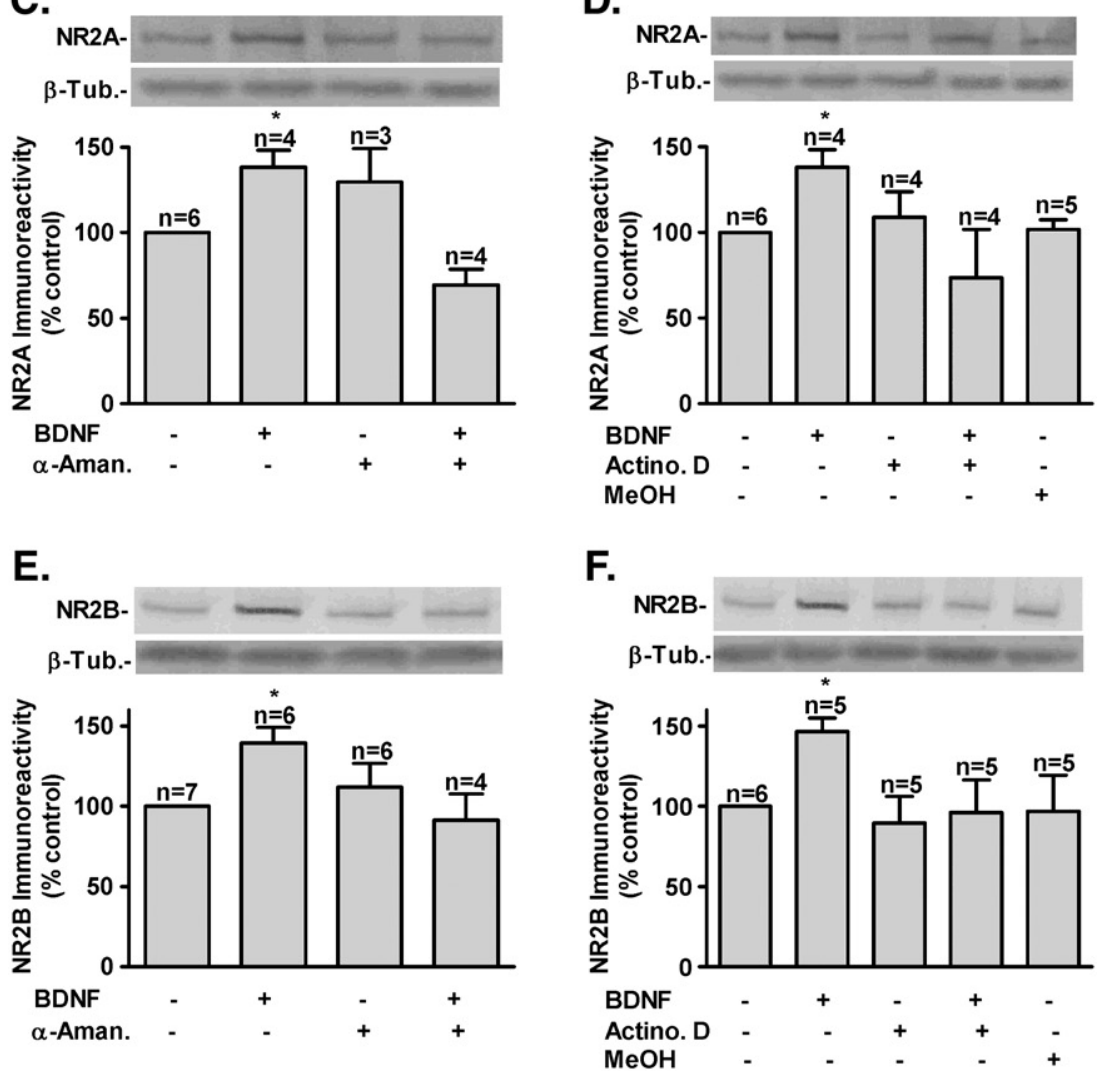

Fig. 5. Transcription inhibitors prevent the BDNF-induced upregulation of the NR1, NR2A and NR2B protein levels. Seven DIV cultured hippocampal neurons were incubated with or without $100 \mathrm{ng} / \mathrm{ml} \mathrm{BDNF}$ for $3 \mathrm{~h}$, in the presence or in the absence of $\alpha$-amanitine $(1.5 \mu \mathrm{M})(\mathrm{A}$, $\mathrm{C}$, E) or actinomycin $\mathrm{D}$ $(1.5 \mu \mathrm{M})(\mathrm{B}, \mathrm{D}, \mathrm{F})$. When the inhibitors were used the cells were pre-incubated with the compounds for 30 min before stimulation with BDNF. Total NR1, NR2A and NR2B protein levels were measured by Western Blot. Control protein levels of NMDA receptor subunits were set to $100 \%$. $\beta$-tubulin was used as loading control. The results are the average \pm S.E.M. of 5-10 independent experiments, performed in independent preparations. Statistical analysis was performed by one-way ANOVA, followed by the Dunnett's test. ${ }^{*} P<0.05$.

pre-incubation of the cells with BDNF. Taken together, these results strongly suggest that the BDNF-induced increase in the $\left[\mathrm{Ca}^{2+}\right]_{\mathrm{i}}$ responses to NMDA are due, at least in part, to an upregulation of the plasma membrane-associated receptors.

\section{Discussion}

BDNF has been shown to play important roles in the regulation of the glutamatergic synaptic transmission and in the early- and latephases of LTP (reviewed in Bramham and Messaoudi, 2005), but the underlying mechanisms are still not fully understood. The rapid effects of BDNF on the post-synaptic responses to glutamate have been largely attributed to the phosphorylation of NMDA receptor subunits, which increases receptor activity (Levine et al., 1998; Levine and Kolb, 2000). In the present study, we showed that BDNF also induces a rapid delivery of NR2B-containing NMDA receptors to the plasma membrane, which correlated with an increased $\left[\mathrm{Ca}^{2+}\right]_{\mathrm{i}}$ response to the activation of the receptors. Furthermore, we showed that BDNF differentially upregulates the NR1, NR2A and NR2B NMDA receptor subunits in cultured hippocampal neurons through 


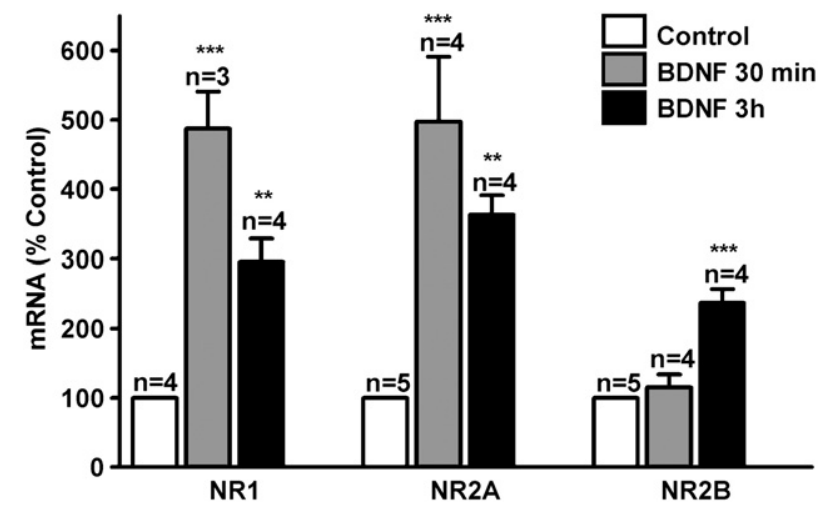

Fig. 6. BDNF increases the mRNA levels of the NR1, NR2A and NR2B NMDA receptor subunits. The variation of NR1, NR2A and NR2B mRNA levels was assayed by SYBR Green real-time PCR of total RNA samples, converted to cDNA in reactions normalized to contain equal amounts of mRNA. The cells (7 DIV) were incubated in the presence or in the absence of $100 \mathrm{ng} / \mathrm{ml} \mathrm{BDNF}$, during $30 \mathrm{~min}$ (gray columns) or $3 \mathrm{~h}$ (black columns). The results are presented as mean percentage \pm S.E.M. compared to the control (unstimulated), and normalized to the reference gene $18 \mathrm{~S}$, and are the average \pm S.E.M. of 3-7 independent experiments, performed in independent preparations. Statistical analysis was performed by one-way ANOVA, followed by the Dunnett's test. ${ }^{* *} P<0.01,{ }^{* * *} P<0.001$.

an increase in transcription activity. The NT3, which binds to a different Trk receptor (TrkC), increased the protein levels of NR2A and NR2B subunits, but was without effect on NR1. The results showing the BDNF-induced rapid delivery of NR1 and NR2 subunits to the plasma membrane contribute to the growing evidence that the surface expression of NMDA receptors is dynamic and regulated (Lan et al., 2001; Roche et al., 2001), as previously documented for AMPA receptors (Gomes et al., 2003). If BDNF has a similar effect on the delivery of NMDA receptors to the synapse, this may account, at least in part, for the role of the neurotrophin in synaptic plasticity. The delivery of NMDA receptors to the synapse plays an important role in long-term potentiation, although the NR2 subunit involved may depend on the development stage (Barria and Malinow, 2005; Kim et al., 2005).

Stimulation of hippocampal neurons with BDNF induced a rapid delivery of NR1- and NR2B-containing NMDA receptors to the plasma membrane, but no increase in NR2A was observed for short incubations with the neurotrophin (Fig. 7). This upregulation in plasma membrane-associated NMDA receptor subunits correlated with an increase in the $\left[\mathrm{Ca}^{2+}\right]_{\mathrm{i}}$ responses mediated by the receptor (Fig. 8). The simultaneous effect on the delivery of NR1 and NR2 subunits was as expected, since both subunits are required to form a functional NMDA receptor (Meguro et al., 1992; Monyer et al., 1994; Dingledine et al., 1999), and occurred at a time point when the amount of NR2B was still not significantly changed. The rapid effect of BDNF on the traffic of NR1/NR2B subunits changes the ratio of NR2A- and NR2B-containing NMDA receptors associated with the membrane, and is likely to result in slower excitatory postsynaptic currents (EPSCs) (Monyer et al., 1994). Interestingly, a recent study showed that NR2B-containing receptors carry more calcium charge per unit current than NR2A-containing NMDA receptors (Sobczyk et al., 2005), and we did observe an increased $\left[\mathrm{Ca}^{2+}\right]_{\mathrm{i}}$ response to NMDA in BDNF-treated hippocampal neurons (Fig. 8).

BDNF was previously shown to acutely increase tyrosine phosphorylation of NR2B (but not NR2A) subunits in cortical and hippocampal postsynaptic densities (Lin et al., 1998), and in cultured hippocampal neurons (Alder et al., 2005), and the effect of the neurotrophin on the activity of NMDA receptors in cultured hippocampal neurons is sensitive to inhibitors of NR2B (Crozier et al., 1999; Levine and Kolb, 2000). Our findings indicate that the upregulation of NR2B-containing receptors associated with the membrane accounts, at least in part, for the effect of the neurotrophin on the receptor activity, but the molecular mechanisms involved remain to be determined. The mechanisms mediating the effect of neurotrophins may be similar to those involved in insulininduced rapid delivery of NMDA receptors to the cell surface, since both receptors have tyrosine kinase activity. The effect of insulin occurs via a SNAP-25 mediated form of SNARE-dependent exocytosis, and does not require direct phosphorylation of the C-terminal tails of the receptor protein, but rather of associated targeting, anchoring, or signalling protein(s) (Skeberdis et al., 2001).

In addition to the effect resulting from the upregulation of plasma membrane-associated receptors, phosphorylation of NMDA receptors may also change their electrophysiological properties, and therefore may contribute to the change in activity induced by BDNF (Fig. 8). BDNF acutely induces phosphorylation
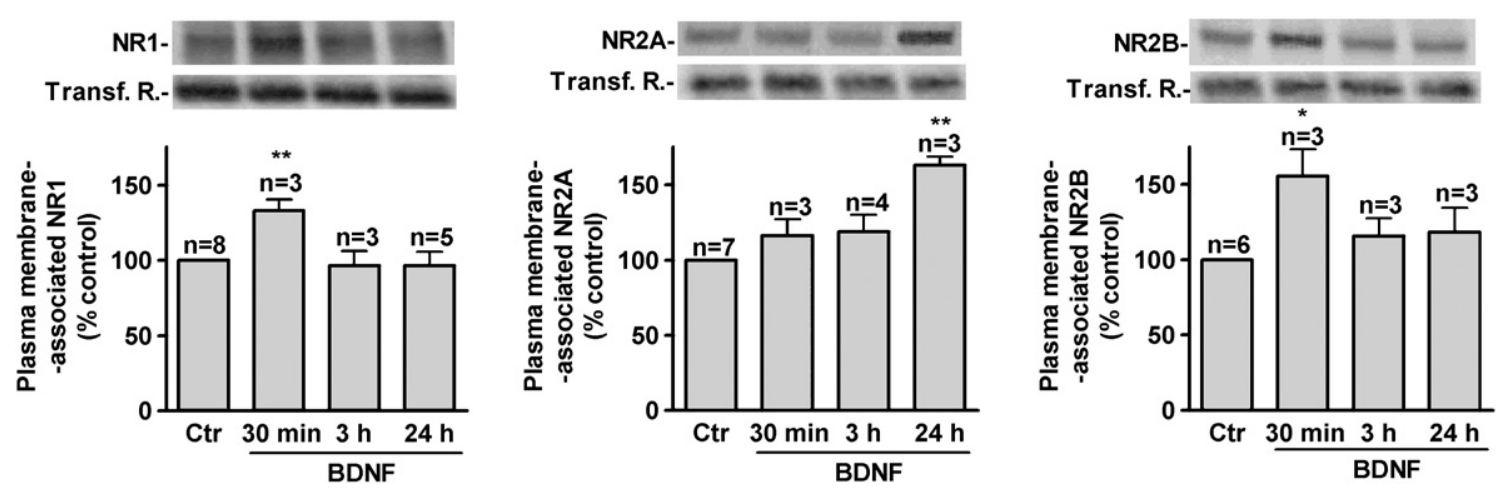

Fig. 7. BDNF increases the NR1, NR2A and NR2B subunits in the plasma membrane. Neurons were treated with or without 100 ng/ml BDNF ( 30 min, $3 \mathrm{~h}$ and $24 \mathrm{~h}$ ). Following treatment, cell surface proteins were labelled by biotinylation, followed by precipitation with streptavidin beads. The abundance of each subunit in the plasma membrane was then determined by Western Blot. Control $(0 \mathrm{~h})$ expression of NMDA subunits protein was set to $100 \%$. The transferrin receptor was used as loading control. The results are the average \pm S.E.M. of 3-8 independent experiments, performed in independent preparations. Statistical analysis was performed by one-way ANOVA, followed by the Dunnett's test. $* P<0.05, * * P<0.01$. 

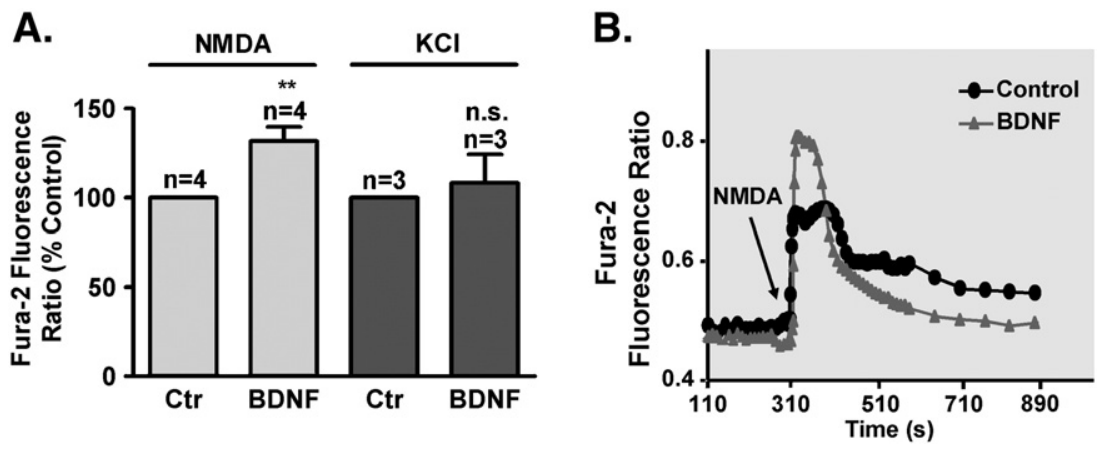

Fig. 8. BDNF increases in the $\left[\mathrm{Ca}^{2+}\right]_{\mathrm{i}}$ responses to NMDA. Cultured hippocampal neurons were loaded with the Fura-2 fluorescence probe in the presence or in the absence of $100 \mathrm{ng} / \mathrm{ml} \mathrm{BDNF}$ for $40 \mathrm{~min}$. Following incubation, cells were perfused with $\mathrm{Mg}^{2+}$-free $\mathrm{Na}^{+}$-salt solution for 5 min and were stimulated with $100 \mu \mathrm{M}$ NMDA and $10 \mu \mathrm{M}$ glycine or $30 \mathrm{mM} \mathrm{KCl}$ for $30 \mathrm{~s}$. After stimulation neurons were perfused with $\mathrm{Mg}^{2+}$-free $\mathrm{Na}^{+}$-salt solution for $10 \mathrm{~min}$. The maximal $\left[\mathrm{Ca}^{2+}\right]_{\mathrm{i}}$ response to $\mathrm{K}^{+}$depolarization or to NMDA-receptor stimulation was monitored in single cells as the ratio between the fluorescence at $340 \mathrm{~nm}$ and $380 \mathrm{~nm}$. For each experimental condition, the control $\left[\mathrm{Ca}^{2+}\right]_{\mathrm{i}}$ responses were set to $100 \%$. The results are the average \pm S.E.M. of 3-4 independent experiments, performed in independent preparations. Each experimental condition was performed in duplicate, and about 80-100 cells were analysed in each field of the microscope. Statistical analysis was performed using the Student's $t$ test. ${ }^{* *} P<0.01$.

of NR1 and NR2B subunits in rat hippocampal postsynaptic densities (Suen et al., 1997; Lin et al., 1998; Alder et al., 2005), and increases NMDA single channel open probability in cultured hippocampal neurons (Levine et al., 1998; Levine and Kolb, 2000). Phosphorylation of NR2B may be mediated by Fyn, a member of the Src family, since this kinase is activated by TrkB receptors (Narisawa-Saito et al., 1999b), and increases currents mediated by recombinant NMDA receptor (Kohr and Seeburg, 1996). The activity of NMDA receptors in CNS neurons was also shown to increase following intracellular application of recombinant $\mathrm{Src}$ (Wang and Salter, 1994; Kalia et al., 2004; Salter and Kalia, 2004), and Fyn-mediated interaction between BDNF signaling and NMDA receptors may play an important role in spatial learning and memory (Mizuno et al., 2003). The signalling activity induced by BDNF may also affect NMDA receptors through protein kinase $\mathrm{C}$, which modulates NMDA receptor trafficking and gating in cultured hippocampal neurons (Lan et al., 2001). In fact, activation of Trk receptors promotes PLC $\gamma$ activity (Chao, 2003), giving rise to diacylglicerol which activates PKC.

In contrast with the short-term effects of BDNF on the surface expression of NR1 and NR2B subunits, longer incubations with BDNF (24 h) increased the amount of NR2A subunits associated with the plasma membrane, but not of NR2B, further indicating that the traffic of the two subunits to the membrane is differentially affected by the neurotrophin. The delayed increase in NR2A in the membrane induced by BDNF may be secondary to the upregulation of the subunit induced by BDNF (Fig. 1) and/or due to changes in abundance of regulatory, motor or anchoring proteins that regulate the traffic of the receptor, since after $24 \mathrm{~h}$ of stimulation of the Trk receptors with the neurotrophin the receptors are no longer active (Almeida et al., 2005). However, it was surprising not to observe an increase of NR1 associated with the membrane, together with NR2A, after long incubations with BDNF. Although this may suggest that the delivered receptors contain more NR2A than NR1 subunits, this hypothesis is against evidences suggesting that the NMDA receptor channels are formed as dimers of dimers (an NR1 dimmer and a NR2 dimmer) (Schorge and Colquhoun, 2003). This BDNF-induced upregulation of NR2A associated with the plasma membrane after long incubation periods with the neurotrophin resembles the shift from NR2B to NR2A observed in developing neurons (Watanabe et al., 1992; Sheng et al., 1994; Barria and
Malinow, 2002; Erisir and Harris, 2003; Kobayashi et al., 2006), resulting in faster excitatory postsynaptic currents (EPSCs) and lower sensitivity to NR2B-selective antagonists (Carmignoto and Vicini, 1992; Flint et al., 1997). This change is also thought to contribute to the developmental changes in NMDA-receptor mediated plasticity at glutamatergic synapses (Philpot et al., 2001).

In addition to the translocation of NMDA receptor subunits to the plasma membrane, we also found that BDNF upregulated NR1, NR2A and NR2B subunits, by a mechanism involving transcription activation. This is supported by the results showing an increase in the mRNA levels for the three subunits in hippocampal neurons stimulated with BDNF (Fig. 6) and the inhibition of neurotrophininduced upregulation of NR1, NR2A and NR2B in the presence of transcription inhibitors (Fig. 5). Therefore, although Trk receptor activation by neurotrophins may stimulate protein synthesis directly (Takei et al., 2004), without transcription induction, this mechanism is not involved in the upregulation of NMDA receptor subunits by BDNF in hippocampal neurons. The effects of BDNF on NMDA receptor subunits were transient in 7 DIV cultures, most likely due to the desensitization of the Trk receptors, followed by a decrease in the intracellular signalling activity (Sommerfeld et al., 2000; Almeida et al., 2005). However, in 14 DIV cultures BDNF induced a sustained increase in the NR1 and NR2A protein levels, but not of NR2B (Fig. 1), which may be due to a change in the turn-over rate of the subunits in the more mature cultures. Interestingly, the expression of NR2A but not NR2B subunit is markedly reduced in the developing cortex of BDNF knockout mice (Margottil and Domenici, 2003). NR1 expression is regulated by different transcription factors, including the NF-kappaB (Liu et al., 2004) or CREB (Lau et al., 2004), and the latter is a major mediator of neuronal neurotrophin responses (Finkbeiner et al., 1997). NR2B expression is also regulated by CREB (Rani et al., 2005), in addition to AP-1 (Qiang and Ticku, 2005), which may also be activated by BDNF-induced signalling (Li et al., 2004). Neurotrophin-4/5 was shown to upregulate NR2A through the immediate early transcription factor Egr-1 in cultured cerebrocortical neurons (Choi et al., 2004).

Stimulation of hippocampal neurons with NT3 for $6 \mathrm{~h}$ also upregulated NR2A and NR2B protein levels, but was without effect on NR1. In contrast with the effect of BDNF, NT3 did not change the NMDA receptor subunit protein levels when $2 \mathrm{~h}$ of incubation 
with the neurotrophin was used. Although the effects of both neurotrophins are likely mediated by Trk receptors (TrkB and TrkC, respectively) the differential responses may be due to a distinct cellular localization of the receptors and/or to differences in the magnitude of the signalling responses induced.

The BDNF-induced upregulation of NMDA receptor subunits and activity that we observed in cultured hippocampal neurons contrast with the lack of effect of BDNF in cerebellar granule neurons incubated with the neurotrophin for $2 \mathrm{~h}$ or $6 \mathrm{~h}$ (Figs. 2D-F), indicating that BDNF has a specific effect on hippocampal neurons. These results contrast with the previously reported downregulation of the NR2A receptor subunits evoked by BDNF in cerebellar granule neurons (Brandoli et al., 1998). This discrepancy may be due to differences in the composition of the culture medium, as well as the use of a distinct concentration of BDNF.

In addition to the long-term effects of BDNF on the abundance and surface expression of NMDA receptors reported in this work, the neurotrophin was also shown to increase the NMDA receptor cluster density and size in cultured hippocampal neurons (Elmariah et al., 2004). Long-term stimulation of cultured cerebrocortical neurons with BDNF also upregulated AMPA receptor subunits and currents (Narisawa-Saito et al., 2002; Nagano et al., 2003), indicating that the neurotrophin has an overall stimulatory effect on excitatory synapses. In contrast with the effects on excitatory synapses, BDNF was shown to reduce rapidly the surface expression of $\mathrm{GABA}_{\mathrm{A}}$ receptors and GABAergic currents in cultured hippocampal neurons (Brunig et al., 2001).

In conclusion, our work shows that BDNF differentially upregulates the plasma membrane associated NMDA receptors, and the protein levels of the receptor subunits in cultured hippocampal neurons. NMDA receptors play an important role in synaptic plasticity, and there is a selective activation of NMDA receptors in specific circuits during memory formation (Tang et al., 1999; Lynch, 2004). The activation of NMDA receptors, together with non-NMDA receptors, induces the synthesis and release of BDNF (Zafra et al., 1990; Hughes et al., 1993) which may further promote NMDA receptor activity by increasing the number of receptors associated with the membrane. The resulting increase in calcium entry through the NMDA receptors will also regulate numerous other downstream signalling pathways, leading to both short-term and long-term neuronal changes (Hardingham and Bading, 2003). If BDNF induces a rapid synaptic delivery of NR2B-containing receptors to the synapse, similarly to the effect observed on the overall surface expression of NMDA receptor subunits, this may be important to allow binding of active CaMKII to synaptic NMDA receptors, thereby contributing to synaptic potentiation (Barria and Malinow, 2005). This model, proposed for developing synapses, contrasts with the role played by NR2A-NMDA receptors in promoting surface expression of GluR1-containing AMPA receptors (Kim et al., 2005), a key event in LTP in more mature synapses (Malinow and Malenka, 2002). Interestingly, BDNF also caused a delayed increase in NR2A associated with the plasma membrane.

\section{Experimental methods}

\section{Hippocampal cultures}

Primary cultures of rat hippocampal neurons were prepared from the hippocampi of E18-E19 Wistar rat embryos, after treatment with trypsin $\left(0.06 \%, 15 \mathrm{~min}, 37{ }^{\circ} \mathrm{C}\right.$; GIBCO Invitrogen, Paisley, UK) and deoxyribonuclease I $(5.36 \mathrm{mg} / \mathrm{ml})$, in $\mathrm{Ca}^{2+}$ - and $\mathrm{Mg}^{2+}$-free Hank's balanced salt

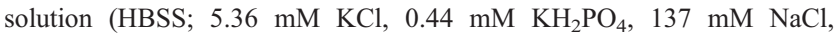

$4.16 \mathrm{mM} \mathrm{NaHCO} 3,0.34 \mathrm{mM} \mathrm{Na} 2 \mathrm{HPO}_{4} \cdot 2 \mathrm{H}_{2} \mathrm{O}, 5 \mathrm{mM}$ glucose, $1 \mathrm{mM}$ sodium pyruvate, $10 \mathrm{mM}$ HEPES and $0.001 \%$ phenol red). The hippocampi were then washed with HBSS containing $10 \%$ fetal bovine serum (BioWittaker Europe, Belgium), to stop trypsin activity, and transferred to Neurobasal medium (GIBCO Invitrogen) supplemented with B27 supplement (1:50 dilution; GIBCO Invitrogen), $25 \mu \mathrm{M}$ glutamate, $0.5 \mathrm{mM}$ glutamine and $0.12 \mathrm{mg} / \mathrm{ml}$ gentamycin. The cells were dissociated in this solution and were then plated in 6 well plates $\left(91.6 \times 10^{3}\right.$ cells $\left./ \mathrm{cm}^{2}\right)$, coated with poly-D-lysine $(0.1 \mathrm{mg} / \mathrm{ml})$, or on poly-D-lysine coated glass coverslips, at a density of $37.5 \times 10^{3}$ cells $/ \mathrm{cm}^{2}$. The cultures were maintained in a humidified incubator of $5 \% \mathrm{CO}_{2} / 95 \%$ air, at $37{ }^{\circ} \mathrm{C}$, for 7 days or 14 days. Cultures were stimulated with $100 \mathrm{ng} / \mathrm{ml} \mathrm{BDNF}$ (kind gift from Regeneron, Tarrytown, NY), $100 \mathrm{ng} / \mathrm{ml}$ heat inactivated (5 min, $95{ }^{\circ} \mathrm{C}$ ) BDNF or with $100 \mathrm{ng} / \mathrm{ml}$ NT3 (Peprotech, London U.K.) for the indicated periods of time. When appropriate, 2.0 $\mu \mathrm{M}$ emetine, 2. $0 \mu \mathrm{M}$ anisomycin, $1.5 \mu \mathrm{M} \alpha$-amanitine or $1.5 \mu \mathrm{M}$ actinomycin $\mathrm{D}$ (Calbiochem, $\mathrm{La}$ Jolla, CA) were added 30 min before stimulation, as indicated.

\section{Cerebellum cultures}

Cerebellar granule neurons were isolated from the cerebella of 7-dayold Sprague-Dawley rats as previously described (Schousboe et al., 1989), with minor modifications. Briefly, following digestion $\left(15 \mathrm{~min}, 37^{\circ} \mathrm{C}\right)$ with $0.2 \%$ trypsin and $0.045 \mathrm{mg} / \mathrm{ml}$ deoxyribonuclease (Sigma) in $\mathrm{Mg}^{2+}$-free $\mathrm{Na}^{+}$-salt solution $\left(120 \mathrm{mM} \mathrm{NaCl}, 5 \mathrm{mM} \mathrm{KCl}, 1.2 \mathrm{KH}_{2} \mathrm{PO}_{4}, 13 \mathrm{mM}\right.$ glucose, $15 \mathrm{mM}$ HEPES, $0.3 \% \mathrm{BSA}, \mathrm{pH}$ 7.4), and dissociation in $0.03 \%$ STI (soybean trypsin inhibitor; Sigma) and $0.04 \mathrm{mg} / \mathrm{ml}$ deoxyribonuclease prepared in $\mathrm{Na}^{+}$-salt solution $\left(120 \mathrm{mM} \mathrm{NaCl}, 5 \mathrm{mM} \mathrm{KCl}, 1.2 \mathrm{KH}_{2} \mathrm{PO}_{4}\right.$, $1.2 \mathrm{mM} \mathrm{MgSO}_{4}, 13 \mathrm{mM}$ glucose, $15 \mathrm{mM}$ HEPES, 0.3\% BSA, pH 7.4), the dissociated cells were centrifuged at $196 \times g$, and washed with Basal Medium Eagle (BME, Sigma), supplemented with $25 \mathrm{mM} \mathrm{KCl}, 30 \mathrm{mM}$ glucose, $26 \mathrm{mM} \mathrm{NaHCO} 3,100 \mathrm{U} / \mathrm{ml}$ penicillin, $0.1 \mathrm{mg} / \mathrm{ml}$ streptomycin and $10 \%$ fetal calf serum (BioWittaker Europe). Neurons were then plated on 6 well plates $\left(34.4 \times 10^{4}\right.$ cells $\left./ \mathrm{cm}^{2}\right)$, coated with poly-D-lysine $(0.1 \mathrm{mg} /$ $\mathrm{ml})$, and cultured in supplemented BME. Approximately $24 \mathrm{~h}$ after plating, $10 \mu \mathrm{M}$ cytosine-1- $\beta$-D-arabino-furanoside (Sigma) was added to the culture medium to prevent glial proliferation. The cultures were maintained in a humidified incubator of $5 \% \mathrm{CO}_{2} / 95 \%$ air, at $37{ }^{\circ} \mathrm{C}$, for 8 days. Cultures were stimulated with $100 \mathrm{ng} / \mathrm{ml}$ BDNF (kind gift from Regeneron) for the indicated periods of time.

\section{Preparation of extracts}

Hippocampal and cerebellar granule neurons were washed twice with ice-cold PBS and once more with PBS buffer supplemented with $1 \mathrm{mM}$ DTT and a cocktail of protease inhibitors $(0.1 \mathrm{mM}$ PMSF, CLAP: $1 \mu \mathrm{g} / \mathrm{ml}$ chymostatin, $1 \mu \mathrm{g} / \mathrm{ml}$ leupeptin, $1 \mu \mathrm{g} / \mathrm{ml}$ antipain, $1 \mu \mathrm{g} / \mathrm{ml}$ pepstatin; Sigma-Aldrich Química, Sintra, Portugal). The cells were then lysed with RIPA (150 mM NaCl, $50 \mathrm{mM}$ Tris- $\mathrm{HCl}, \mathrm{pH}$ 7.4, $5 \mathrm{mM}$ EGTA, $1 \%$ Triton, $0.5 \%$ DOC and $0.1 \%$ SDS at a final $\mathrm{pH} 7.5$ ) supplemented with the cocktail of protease inhibitors. After centrifugation at $16,100 \times \mathrm{g}$ for $10 \mathrm{~min}$, protein in the supernatants was quantified using the BCA method, and the samples were denaturated with $2 \times$ concentrated denaturating buffer (125 mM Tris, pH 6.8, $100 \mathrm{mM}$ glycine, 4\% SDS, $200 \mathrm{mM}$ DTT, 40\% glycerol, $3 \mathrm{mM}$ sodium orthovanadate, and $0.01 \%$ bromophenol blue), at $95{ }^{\circ} \mathrm{C}$ for $5 \mathrm{~min}$. NMDA receptor subunits were then analysed by Western Blot.

\section{Total RNA isolation and reverse transcription for Real-Time PCR}

Total RNA from 7 DIV cultured hippocampal neurons was extracted with TRizol reagent (Invitrogen, Barcelona, Spain), according to the instructions of the manufacturer. The full content of a 6 well cell cluster plate, with 870,000 cells/well (DIV 7), was collected for each experimental condition. For first strand cDNA synthesis, $3 \mu \mathrm{g}$ of total RNA were reversetranscribed with AMV Reverse Transcriptase (Roche, Carnaxide, Portugal), using Random Primer $\mathrm{p}(\mathrm{dN})_{6}(3.2 \mu \mathrm{g})$, dNTPs (1 mM each), $\mathrm{MgCl}_{2}$ 
(25 mM), RNase inhibitor (50 units) and Gelatine $(0.01 \mu \mathrm{g} / \mu \mathrm{l})$, in Reaction Buffer (10 mM Tris, $50 \mathrm{mM} \mathrm{KCl,} \mathrm{pH} \mathrm{8.3)} \mathrm{and} \mathrm{in} \mathrm{a} \mathrm{total} \mathrm{volume} \mathrm{of} 40 \mu 1$. The reaction was performed at $25{ }^{\circ} \mathrm{C}$ for $10 \mathrm{~min}$, followed by $60 \mathrm{~min}$ at $42{ }^{\circ} \mathrm{C}$, for primer annealing to the RNA template and cDNA synthesis, respectively. The Reverse Transcriptase was then denatured during $5 \mathrm{~min}$ at $99{ }^{\circ} \mathrm{C}$, and the sample was cooled to $4{ }^{\circ} \mathrm{C}$ for $5 \mathrm{~min}$ and finally stored at $-80{ }^{\circ} \mathrm{C}$ until further use.

\section{Real-Time PCR}

Real-Time PCR analysis of gene expression was performed using the LightCycler System II (Roche, Portugal). The PCR reactions were performed using LightCycler FastStart DNA Master SYBR Green I (Roche et al.) in $20 \mu \mathrm{l}$ capillaries. The primers used for amplification of genes encoding NMDA receptor subunits were, respectively, RNFRIF2079-5' TAC ACT GCC AAC TTG GCA GCT TTC3' and RNRIR2591-5'CAT GAA GAC CCC TGC CAT GTT3' for NR1, RNRZAF1961-5'TGG CTG CCT TCA TGA TCC A3' and RNRZAR2312-5'TGC AGC GCA ATT CCA TAG C3' for NR2A, and RNRZBF1040-5'GGA TCT ACC AGT CTA ACA TG3' and RIRNRZBR1602- $5^{\prime}$ GAT AGT TAG TGA TCC CAC TG3' for NR2B. The primers used for the amplification of endogenous control gene 18S rRNA were those included in the Applied Biosystems TaqMan Ribosomal RNA Control Reagents Kit (Porto, Portugal). Each primer of a pair was added to the reaction mixture $(10 \mu \mathrm{l})$ at a final concentration of $0.8 \mu \mathrm{M}$ with $3 \mathrm{mM} \mathrm{MgCl}_{2}$, in addition to the "Hot Start" LightCycler Fast Start DNA Master SYBR Green I mix $(1 \times)$ and $1.2 \mu \mathrm{lof}$ cDNA sample. Thermal cycling was initiated with activation of the FastStart Taq DNA Polymerase by denaturation during $10 \mathrm{~min}$ at $95^{\circ} \mathrm{C}$, followed by 45 cycles of a $30 \mathrm{~s}$ melting step at $95^{\circ} \mathrm{C}$, a $5 \mathrm{~s}$ annealing step at $58^{\circ} \mathrm{C}$, and a $25 \mathrm{~s}$ elongation step at $72{ }^{\circ} \mathrm{C}$ (all temperature transition rates at $20^{\circ} \mathrm{C} / \mathrm{s}$ ). After amplification for 45 cycles, at least 10 cycles beyond the beginning of the linear phase of amplification, samples were subjected to a melting curve analysis according to the instructions of the manufacturer in order to confirm the absence of unspecific amplification products and primer-dimers. In all experiments, samples containing no template were included as negative controls.

\section{mRNA quantitative analysis}

The mRNA levels of the constitutively expressed housekeeping gene encoding $18 \mathrm{~S}$ ribosomal RNA were used as a control, in all experiments. The relative changes in the mRNA levels of glutamate receptor subunits in cultured hippocampal neurons were determined using the $\Delta \Delta \mathrm{Cp}$ method. Accordingly, for each experimental condition (unstimulated neurons and neurons treated with $100 \mathrm{ng} / \mathrm{ml} \mathrm{BDNF}$ for $30 \mathrm{~min}$ or $3 \mathrm{~h}$ ) the "Crossing point" $(\mathrm{Cp})$ values given by the LightCycler system II software, for each target gene, were subtracted by the respective $\mathrm{Cp}$ value determined for the $18 \mathrm{~S}$ gene for the same sample and condition $(\Delta \mathrm{Cp})$. This allows normalizing changes in target gene expression. Afterwards, the $\Delta \mathrm{Cp}$ values were subtracted by the respective values of the control for the target gene giving $\Delta \Delta \mathrm{Cp}$. The derivation to the formula $2^{-(\Delta \Delta \mathrm{Cp})}$ sets each control at the unity (or $100 \%$ ), since $\Delta \Delta \mathrm{Cp}$ (control) $=0$ and the stimuli conditions used were at a percentage relative to the control.

\section{Surface biotinylation and precipitation}

Hippocampal cell cultures (7 DIV) were treated or not with $100 \mathrm{ng} / \mathrm{ml}$ BDNF and then incubated with $1 \mathrm{mg} / \mathrm{ml}$ EZ-Link ${ }^{\mathrm{TM}}$ Sulfo-NHS-SS-biotin (Pierce, Madison, WI) in ice-cold PBS containing $1 \mathrm{mM} \mathrm{CaCl}_{2}$ and $1 \mathrm{mM}$ $\mathrm{MgCl}_{2}$, for $30 \mathrm{~min}$ (Gomes et al., 2004). The non-bound biotin was removed by washing the cells with PBS containing $100 \mathrm{mM}$ glycine. Cell lysates were obtained as described above, and were incubated with UltraLink Plus ${ }^{\mathrm{TM}}$ immobilized streptavidin beads (Pierce), for $2 \mathrm{~h}$ at $4{ }^{\circ} \mathrm{C}$, under constant agitation. Non-biotinylated proteins were removed by centrifugation at $2500 \times \mathrm{g}$ for $3 \mathrm{~min}$, and the beads were washed three times with RIPA buffer. Biotinylated proteins were then eluted with denaturating buffer at $95^{\circ} \mathrm{C}$ for $5 \mathrm{~min}$. Samples were then processed for Western Blotting analysis.

\section{Western blotting}

Protein samples were separated by SDS-PAGE, in 6\% polyacrylamide gels, transferred to polyvinylidene (PVDF) membranes (BioRad, Amadora, Portugal), and immunoblotted. Blots were incubated with primary antibodies (overnight at $4{ }^{\circ} \mathrm{C}$ ), washed and exposed to alkaline phosphatase-conjugated secondary antibodies (1:20000 dilution; $1 \mathrm{~h}$ at room temperature). Alkaline phosphatase activity was visualized by ECF on the Storm $860 \mathrm{Gel}$ and Blot Imaging System (Amersham Biosciences, Buckinghamshire, UK). The following primary antibodies were used: anti-NR1 (1:200, Chemicon International, Temecula, CA), anti-NR2A (1:750, Chemicon International, Temecula, CA or 1:300, BD Transduction Laboratories, Erembodegem, Belgium) and anti-NR2B (1:400, BD Transduction Laboratories). Anti- $\beta$ Tubulin I (1:700,000; Sigma) and anti-transferrin receptor (1:3000; Zymed, South San Francisco, CA) antibodies were used as loading controls.

Single cell $\left[\mathrm{Ca}^{2+}\right]_{i}$ measurements

Changes in the $\left[\mathrm{Ca}^{2+}\right]_{\mathrm{i}}$ were assessed by monitoring the Fura-2 (Invitrogen-Molecular Probes, Leiden, The Netherlands) fluorescence ratio (F340/F380). Seven DIV hippocampal neurons were loaded in a $\mathrm{Mg}^{2+}$-free $\mathrm{Na}^{+}$-salt solution $\left(132 \mathrm{mM} \mathrm{NaCl}, 4 \mathrm{mM} \mathrm{KCl}, 2.5 \mathrm{mM} \mathrm{CaCl}_{2}, 6 \mathrm{mM}\right.$ Glucose, $10 \mathrm{mM}$ Hepes, $10 \mathrm{mM} \mathrm{NaHCO}$, pH 7.4) containing $5 \mu \mathrm{g} / \mathrm{ml} \mathrm{Fura-2/AM,}$ $0.2 \%$ pluronic acid F-127 (Invitrogen-Molecular Probes) and $0.1 \%$ fatty acid-free bovine serum albumin, in the presence or absence of $100 \mathrm{ng} / \mathrm{ml}$ BDNF, for $40 \mathrm{~min}$ at $37{ }^{\circ} \mathrm{C}$. After incubation, the glass coverslips were mounted on a RC-20 chamber in a PH3 platform (Warner Instruments, Hamden, CT), at room temperature, on the stage of an inverted fluorescence microscope Axiovert 200 (Zeiss). Neurons were continuously perfused with a $\mathrm{Mg}^{2+}$-free $\mathrm{Na}^{+}$-salt solution, for $5 \mathrm{~min}$, and were then stimulated with $100 \mu \mathrm{M}$ NMDA and $10 \mu \mathrm{M}$ glycine, or with $30 \mathrm{mM} \mathrm{KCl}\left(\mathrm{Na}^{+}\right.$was isoosmotically replaced by $\mathrm{KCl}$ ), for $30 \mathrm{~s}$. After stimulation neurons were again perfused with a $\mathrm{Mg}^{2+}$-free $\mathrm{Na}^{+}$-salt solution, for $10 \mathrm{~min}$. Solutions were added to the cells by a fast-pressurized ( $95 \%$ air, $5 \% \mathrm{CO}_{2}$ atmosphere) system (AutoMate Scientific Inc, San Francisco, CA). The cells were alternately excited at 340 and $380 \mathrm{~nm}$ using a Lambda DG4 apparatus (Sutter Instruments Company, Novato, CA). Changes in the fluorescence ratio of Fura- 2 were acquired with a $40 \times$ objective and a CollSNAP HQ digital camera (Roper Scientific, Tucson, AZ), and processed using the MetaFluor software (Universal Imaging Corporation, Downingtown, PA). The results are presented as the ratio of fluorescence intensities after excitation at $340 \mathrm{~nm}$ and at $380 \mathrm{~nm}$.

\section{Statistical analysis}

Statistical analysis was performed using one-way ANOVA analysis of variance followed by the Dunnett's test, or Bonferroni test, or using the Student's $t$ test, as indicated in the figure captions.

\section{Acknowledgments}

We would like to thank Dr. Gina Marrão (Faculty of Medicine, University of Coimbra) for gently providing us the use of the LightCycler System II, Regeneron for the kind gift of BDNF and Fundação para a Ciência e Tecnologia and FEDER for financial support (grants POCTI/BCI/46466/2002 and SFRH/BD/9692/ 2002). We also thank Elisabete Carvalho for assistance in the preparations of cell cultures.

\section{References}

Alder, J., Thakker-Varia, S., Crozier, R.A., Shaheen, A., Plummer, M.R., Black, I.B., 2005. Early presynaptic and late postsynaptic components contribute independently to brain-derived neurotrophic factor-induced synaptic plasticity. J. Neurosci. 25, 3080-3085. 
Almeida, R.D., Manadas, B.J., Melo, C.V., Gomes, J.R., Mendes, C.S., Graos, M.M., Carvalho, R.F., Carvalho, A.P., Duarte, C.B., 2005. Neuroprotection by BDNF against glutamate-induced apoptotic cell death is mediated by ERK and PI3-kinase pathways. Cell Death Differ. 12, 1329-1343

Barria, A., Malinow, R., 2002. Subunit-specific NMDA receptor trafficking to synapses. Neuron 35, 345-353.

Barria, A., Malinow, R., 2005. NMDA receptor subunit composition controls synaptic plasticity by regulating binding to CaMKII. Neuron 48, 289-301.

Bramham, C.R., Messaoudi, E., 2005. BDNF function in adult synaptic plasticity: the synaptic consolidation hypothesis. Prog. Neurobiol. 76, 99-125.

Brandoli, C., Sanna, A., De Bernardi, M.A., Follesa, P., Brooker, G., Mocchetti, I., 1998. Brain-derived neurotrophic factor and basic fibroblast growth factor downregulate NMDA receptor function in cerebellar granule cells. J. Neurosci. 18, 7953-7961.

Brunig, I., Penschuck, S., Berninger, B., Benson, J., Fritschy, J.M., 2001. BDNF reduces miniature inhibitory postsynaptic currents by rapid downregulation of $\mathrm{GABA}_{\mathrm{A}}$ receptor surface expression. Eur. J. Neurosci. 13, 1320-1328.

Carmignoto, G., Vicini, S., 1992. Activity-dependent decrease in NMDA receptor responses during development of the visual cortex. Science 258, 1007-1011.

Chao, M.V., 2003. Neurotrophins and their receptors: a convergence point for many signalling pathways. Nat. Rev., Neurosci. 4, 299-309.

Chatterton, J.E., Awobuluyi, M., Premkumar, L.S., Takahashi, H., Talantova, M., Shin, Y., Cui, J., Tu, S., Sevarino, K.A., Nakanishi, N., Tong, G., Lipton, S.A., Zhang, D., 2002. Excitatory glycine receptors containing the NR3 family of NMDA receptor subunits. Nature 415, 793-798.

Choi, S.Y., Hwang, J.J., Koh, J.Y., 2004. NR2A induction and NMDA receptor-dependent neuronal death by neurotrophin- $4 / 5$ in cortical cell culture. J. Neurochem. 88, 708-716.

Crozier, R.A., Black, I.B., Plummer, M.R., 1999. Blockade of NR2Bcontaining NMDA receptors prevents BDNF enhancement of glutamatergic transmission in hippocampal neurons. Learn. Mem. 6, $257-266$

Dechant, G., 2001. Molecular interactions between neurotrophin receptors. Cell Tissue Res. 305, 229-238.

Dingledine, R., Borges, K., Bowie, D., Traynelis, S.F., 1999. The glutamate receptor ion channels. Pharmacol. Rev. 51, 7-61.

Duarte, C.B., Santos, P.F., Carvalho, A.P., 1996. $\left[\mathrm{Ca}^{2+}\right]_{\mathrm{i}}$ regulation by glutamate receptor agonists in cultured chick retina cells. Vision Res. 36, 1091-1102.

Elmariah, S.B., Crumling, M.A., Parsons, T.D., Balice-Gordon, R.J., 2004. Postsynaptic TrkB-mediated signaling modulates excitatory and inhibitory neurotransmitter receptor clustering at hippocampal synapses. J. Neurosci. 24, 2380-2393.

Erisir, A., Harris, J.L., 2003. Decline of the critical period of visual plasticity is concurrent with the reduction of NR2B subunit of the synaptic NMDA receptor in layer 4. J. Neurosci. 23, 5208-5218.

Finkbeiner, S., Tavazoie, S.F., Maloratsky, A., Jacobs, K.M., Harris, K.M., Greenberg, M.E., 1997. CREB: A major mediator of neuronal neurotrophin responses. Neuron 19, 1031-1047.

Fletcher, T.L., Cameron, P., De Camilli, P., Banker, G., 1991. The distribution of synapsin I and synaptophysin in hippocampal neurons developing in culture. J. Neurosci. 11, 1617-1626.

Flint, A.C., Maisch, U.S., Weishaupt, J.H., Kriegstein, A.R., Monyer, H., 1997. NR2A subunit expression shortens NMDA receptor synaptic currents in developing neocortex. J. Neurosci. 17, 2469-2476.

Gomes, A.R., Correia, S.S., Carvalho, A.L., Duarte, C.B., 2003. Regulation of AMPA receptor activity, synaptic targeting and recycling: role in synaptic plasticity. Neurochem. Res. 28, 1459-1473.

Gomes, A.R., Cunha, P., Nuriya, M., Faro, C.J., Huganir, R.L., Pires, E.V., Carvalho, A.L., Duarte, C.B., 2004. Metabotropic glutamate and dopamine receptors co-regulate AMPA receptor activity through PKA in cultured chick retinal neurones: effect on GluR4 phosphorylation and surface expression. J. Neurochem. 90, 673-682.

Hall, R.A., Soderling, T.R., 1997. Differential surface expression and phosphorylation of the $N$-methyl-D-aspartate receptor subunits NR1 and NR2 in cultured hippocampal neurons. J. Biol. Chem. 272, 4135-4140.

Hardingham, G.E., Bading, H., 2003. The Yin and Yang of NMDA receptor signalling. Trends Neurosci. 26, 81-89.

Hughes, P., Beilharz, E., Gluckman, P., Dragunow, M., 1993. Brain-derived neurotrophic factor is induced as an immediate early gene following $N$-methyl-D-aspartate receptor activation. Neuroscience 57, 319-328.

Huh, K.H., Wenthold, R.J., 1999. Turnover analysis of glutamate receptors identifies a rapidly degraded pool of the $N$-methyl-D-aspartate receptor subunit, NR1, in cultured cerebellar granule cells. J. Biol. Chem. 274, $151-157$.

Janssens, N., Lesage, A.S., 2001. Glutamate receptor subunit expression in primary neuronal and secondary glial cultures. J. Neurochem. 77, 1457-1474.

Kalb, R., 2005. The protean actions of neurotrophins and their receptors on the life and death of neurons. Trends Neurosci. 28, 5-11.

Kalia, L.V., Gingrich, J.R., Salter, M.W., 2004. Src in synaptic transmission and plasticity. Oncogene 23, 8007-8016.

Kim, M.J., Dunah, A.W., Wang, Y.T., Sheng, M., 2005. Differential roles of NR2A- and NR2B-containing NMDA receptors in Ras-ERK signaling and AMPA receptor trafficking. Neuron 46, 745-760.

Kobayashi, K., Tsuji, R., Yoshioka, T., Mino, T., Seki, T., 2006. Perinatal exposure to PTU delays switching from NR2B to NR2A subunits of the NMDA receptor in the rat cerebellum. Neurotoxicology 27, 284-290.

Kohr, G., Seeburg, P.H., 1996. Subtype-specific regulation of recombinant NMDA receptor-channels by protein tyrosine kinases of the src family. J. Physiol. 492 (Pt. 2), 445-452.

Lan, J.Y., Skeberdis, V.A., Jover, T., Grooms, S.Y., Lin, Y., Araneda, R.C., Zheng, X., Bennett, M.V., Zukin, R.S., 2001. Protein kinase C modulates NMDA receptor trafficking and gating. Nat. Neurosci. 4, 382-390.

Lau, G.C., Saha, S., Faris, R., Russek, S.J., 2004. Up-regulation of NMDAR1 subunit gene expression in cortical neurons via a PKAdependent pathway. J. Neurochem. 88, 564-575.

Lessmann, V., Heumann, R., 1998. Modulation of unitary glutamatergic synapses by neurotrophin- $4 / 5$ or brain-derived neurotrophic factor in hippocampal microcultures: presynaptic enhancement depends on preestablished paired-pulse facilitation. Neuroscience 86, 399-413.

Levine, E.S., Kolb, J.E., 2000. Brain-derived neurotrophic factor increases activity of NR2B-containing $N$-methyl-D-aspartate receptors in excised patches from hippocampal neurons. J. Neurosci. Res. 62, 357-362.

Levine, E.S., Crozier, R.A., Black, I.B., Plummer, M.R., 1998. Brainderived neurotrophic factor modulates hippocampal synaptic transmission by increasing $N$-methyl-D-aspartic acid receptor activity. Proc. Natl. Acad. Sci. U. S. A. 95, 10235-10239.

Li, Z., Ding, M., Thiele, C.J., Luo, J., 2004. Ethanol inhibits brain-derived neurotrophic factor-mediated intracellular signaling and activator protein-1 activation in cerebellar granule neurons. Neuroscience 126 149-162

Lin, S.Y., Wu, K., Levine, E.S., Mount, H.T., Suen, P.C., Black, I.B., 1998. BDNF acutely increases tyrosine phosphorylation of the NMDA receptor subunit $2 \mathrm{~B}$ in cortical and hippocampal postsynaptic densities. Brain Res. Mol. Brain Res. 55, 20-27.

Liu, A., Hoffman, P.W., Lu, W., Bai, G., 2004. NF-kappaB site interacts with Sp factors and up-regulates the NR1 promoter during neuronal differentiation. J. Biol. Chem. 279, 17449-17458.

Lu, B., Pang, P.T., Woo, N.H., 2005. The yin and yang of neurotrophin action. Nat. Rev. Neurosci. 6, 603-614.

Lynch, M.A., 2004. Long-term potentiation and memory. Physiol. Rev. 84, $87-136$.

Malinow, R., Malenka, R.C., 2002. AMPA receptor trafficking and synaptic plasticity. Annu. Rev. Neurosci. 25, 103-126.

Margottil, E., Domenici, L., 2003. NR2A but not NR2B N-methyl-Daspartate receptor subunit is altered in the visual cortex of BDNF-knockout mice. Cell. Mol. Neurobiol. 23, 165-174. 
Meguro, H., Mori, H., Araki, K., Kushiya, E., Kutsuwada, T., Yamazaki, M., Kumanishi, T., Arakawa, M., Sakimura, K., Mishina, M., 1992. Functional characterization of a heteromeric NMDA receptor channel expressed from cloned cDNAs. Nature 357, 70-74.

Messaoudi, E., Ying, S.W., Kanhema, T., Croll, S.D., Bramham, C.R., 2002. Brain-derived neurotrophic factor triggers transcription-dependent, late phase long-term potentiation in vivo. J. Neurosci. 22, 7453-7461.

Mizuno, M., Yamada, K., He, J., Nakajima, A., Nabeshima, T., 2003. Involvement of BDNF receptor TrkB in spatial memory formation. Learn. Mem. 10, 108-115.

Monyer, H., Burnashev, N., Laurie, D.J., Sakmann, B., Seeburg, P.H., 1994. Developmental and regional expression in the rat brain and functional properties of four NMDA receptors. Neuron 12, 529-540.

Muzet, M., Dupont, J.L., 1996. Enhancement of NMDA receptor maturation by BDNF in cultured mouse cerebellar granule cells. NeuroReport 7 , $548-552$.

Nagano, T., Yanagawa, Y., Obata, K., Narisawa-Saito, M., Namba, H., Otsu, Y., Takei, N., Nawa, H., 2003. Brain-derived neurotrophic factor upregulates and maintains AMPA receptor currents in neocortical GABAergic neurons. Mol. Cell. Neurosci. 24, 340-356.

Nakazawa, T., Komai, S., Tezuka, T., Hisatsune, C., Umemori, H., Semba, K., Mishina, M., Manabe, T., Yamamoto, T., 2001. Characterization of Fyn-mediated tyrosine phosphorylation sites on GluR epsilon 2 (NR2B) subunit of the $N$-methyl-D-aspartate receptor. J. Biol. Chem. 276, 693-699.

Narisawa-Saito, M., Carnahan, J., Araki, K., Yamaguchi, T., Nawa, H., 1999a. Brain-derived neurotrophic factor regulates the expression of AMPA receptor proteins in neocortical neurons. Neuroscience 88 , 1009-1014

Narisawa-Saito, M., Silva, A.J., Yamaguchi, T., Hayashi, T., Yamamoto, T., Nawa, H., 1999b. Growth factor-mediated Fyn signaling regulates alphaamino-3-hydroxy-5-methyl-4-isoxazolepropionic acid (AMPA) receptor expression in rodent neocortical neurons. Proc. Natl. Acad. Sci. U. S. A. 96, 2461-2466.

Narisawa-Saito, M., Iwakura, Y., Kawamura, M., Araki, K., Kozaki, S., Takei, N., Nawa, H., 2002. Brain-derived neurotrophic factor regulates surface expression of alpha-amino-3-hydroxy-5-methyl-4-isoxazoleproprionic acid receptors by enhancing the $N$-ethylmaleimide-sensitive factor/GluR2 interaction in developing neocortical neurons. J. Biol. Chem. 277, 40901-40910.

Nong, Y., Huang, Y.Q., Salter, M.W., 2004. NMDA receptors are movin' in. Curr. Opin. Neurobiol. 14, 353-361.

Philpot, B.D., Sekhar, A.K., Shouval, H.Z., Bear, M.F., 2001. Visual experience and deprivation bidirectionally modify the composition and function of NMDA receptors in visual cortex. Neuron 29, 157-169.

Prybylowski, K., Fu, Z., Losi, G., Hawkins, L.M., Luo, J., Chang, K., Wenthold, R.J., Vicini, S., 2002. Relationship between availability of NMDA receptor subunits and their expression at the synapse. J. Neurosci. 22, 8902-8910

Qiang, M., Ticku, M.K., 2005. Role of AP-1 in ethanol-induced $N$-methyl$\mathrm{D}$-aspartate receptor $2 \mathrm{~B}$ subunit gene up-regulation in mouse cortical neurons. J. Neurochem. 95, 1332-1341.

Rani, C.S., Qiang, M., Ticku, M.K., 2005. Potential role of cAMP response element-binding protein in ethanol-induced $N$-methyl-D-aspartate receptor $2 \mathrm{~B}$ subunit gene transcription in fetal mouse cortical cells. Mol. Pharmacol. 67, 2126-2136.

Roche, K.W., Standley, S., McCallum, J., Dune Ly, C., Ehlers, M.D. Wenthold, R.J., 2001. Molecular determinants of NMDA receptor internalization. Nat. Neurosci. 4, 794-802.

Salter, M.W., Kalia, L.V., 2004. Src kinases: a hub for NMDA receptor regulation. Nat. Rev., Neurosci. 5, 317-328.

Schorge, S., Colquhoun, D., 2003. Studies of NMDA receptor function and stoichiometry with truncated and tandem subunits. J. Neurosci. 23, $1151-1158$
Schratt, G.M., Nigh, E.A., Chen, W.G., Hu, L., Greenberg, M.E., 2004. BDNF regulates the translation of a select group of mRNAs by a mammalian target of rapamycin-phosphatidylinositol 3-kinase-dependent pathway during neuronal development. J. Neurosci. 24, 7366-7377.

Schousboe, A., Meier, E., Drejer, J., Herz, L., 1989. Preparation of primary cultures of mouse (rat) cerebellar granule cells. In: Shahar, A., De Vellis, J., Vernadakis, A., Haber, B. (Eds.), A Dissection and Tissue Culture Manual of the Nervous System. Alan R. Liss, New York, pp. 203-206

Sheng, M., Cummings, J., Roldan, L.A., Jan, Y.N., Jan, L.Y., 1994. Changing subunit composition of heteromeric NMDA receptors during development of rat cortex. Nature 368, 144-147.

Skeberdis, V.A., Lan, J., Zheng, X., Zukin, R.S., Bennett, M.V., 2001. Insulin promotes rapid delivery of $\mathrm{N}$-methyl-D-aspartate receptors to the cell surface by exocytosis. Proc. Natl. Acad. Sci. U. S. A. 98, 3561-3566.

Sobczyk, A., Scheuss, V., Svoboda, K., 2005. NMDA receptor subunitdependent $\left[\mathrm{Ca}^{2+}\right]$ signaling in individual hippocampal dendritic spines. J. Neurosci. 25, 6037-6046.

Sommerfeld, M.T., Schweigreiter, R., Barde, Y.A., Hoppe, E., 2000. Downregulation of the neurotrophin receptor TrkB following ligand binding. Evidence for an involvement of the proteasome and differential regulation of TrkA and TrkB. J. Biol. Chem. 275, 8982-8990.

Song, D.K., Choe, B., Bae, J.H., Park, W.K., Han, I.S., Ho, W.K., Earm, Y.E., 1998. Brain-derived neurotrophic factor rapidly potentiates synaptic transmission through NMDA, but suppresses it through non-NMDA receptors in rat hippocampal neuron. Brain Res. 799, $176-179$.

Stocca, G., Vicini, S., 1998. Increased contribution of NR2A subunit to synaptic NMDA receptors in developing rat cortical neurons. J. Physiol. 507 (Pt. 1), 13-24.

Suen, P.C., Wu, K., Levine, E.S., Mount, H.T., Xu, J.L., Lin, S.Y., Black, I.B., 1997. Brain-derived neurotrophic factor rapidly enhances phosphorylation of the postsynaptic $N$-methyl-D-aspartate receptor subunit 1. Proc. Natl. Acad. Sci. U. S. A. 94, 8191-8195.

Takei, N., Numakawa, T., Kozaki, S., Sakai, N., Endo, Y., Takahashi, M., Hatanaka, H., 1998. Brain-derived neurotrophic factor induces rapid and transient release of glutamate through the non-exocytotic pathway from cortical neurons. J. Biol. Chem. 273, 27620-27624.

Takei, N., Kawamura, M., Hara, K., Yonezawa, K., Nawa, H., 2001. Brain-derived neurotrophic factor enhances neuronal translation by activating multiple initiation processes: comparison with the effects of insulin. J. Biol. Chem. 276, 42818-42825.

Takei, N., Inamura, N., Kawamura, M., Namba, H., Hara, K., Yonezawa, K., Nawa, H., 2004. Brain-derived neurotrophic factor induces mammalian target of rapamycin-dependent local activation of translation machinery and protein synthesis in neuronal dendrites. J. Neurosci. 24, 9760-9769.

Tang, Y.P., Shimizu, E., Dube, G.R., Rampon, C., Kerchner, G.A., Zhuo, M., Liu, G., Tsien, J.Z., 1999. Genetic enhancement of learning and memory in mice. Nature 401, 63-69.

Tovar, K.R., Westbrook, G.L., 1999. The incorporation of NMDA receptors with a distinct subunit composition at nascent hippocampal synapses in vitro. J. Neurosci. 19, 4180-4188.

Wang, Y.T., Salter, M.W., 1994. Regulation of NMDA receptors by tyrosine kinases and phosphatases. Nature 369, 233-235.

Watanabe, M., Inoue, Y., Sakimura, K., Mishina, M., 1992. Developmental changes in distribution of NMDA receptor channel subunit mRNAs. NeuroReport 3, 1138-1140.

Zafra, F., Hengerer, B., Leibrock, J., Thoenen, H., Lindholm, D., 1990. Activity dependent regulation of BDNF and NGF mRNAs in the rat hippocampus is mediated by non-NMDA glutamate receptors. EMBO J. $9,3545-3550$ 